\title{
Evaluasi Program Peningkatan Kompetensi Hakim Melalui Pelatihan yang Terintegrasi dan Berkelanjutan di Indonesia ${ }^{1}$
}

\author{
Indriati Amarini \\ Fakultas Hukum Universitas Muhammadiyah Purwokerto \\ Jl. Raya Dukuhwaluh, Dukuhwaluh Kembaran, Jawa Tengah 53182 \\ IndriatiAmarini@ump.ac.id.
}

Received: 14 Desember 2017; Accepted: 25 Februari 2018; Published: 14 Agustus 2018

DOI: 10.20885/iustum.vol25.iss1.art9

\begin{abstract}
The ability of judges to make decisions is acquired from their experiences during the career that they have undergone. The problems formulated in this study were, first why is it necessary to improve the competence of judges through trainings of judges? Second, how is the model of judge competence improvement program aimed to create professional and authoritative judges with high integrity? This was a socio-legal or non-doctrinal research. The results of this study indicated that: first, judge training programs are highly necessary in order to create professional and authoritative judges with high integrity. Besides, these trainings also serve as a means to improve the quality of judge decisions and judge competencies, including professional competence, personal competence, social competence, and leadership competence. Second, the model of judge competence improvement program to create professional and authoritative judges with high integrity is through integrated and continuous trainings.
\end{abstract}

Keywords: Competence; training; judge

Abstrak

Kemampuan hakim mengambil putusan berasal dari pengalaman yang diperoleh selama karir yang dijalani. Rumusan masalah yang diangkat dalam penelitian ini, pertama mengapa diperlukan peningkatan kompetensi hakim melalui program pelatihan-pelatihan hakim? Kedua, bagaimanakah model program peningkatan kompetensi hakim dalam rangka mewujudkan hakim profesional, berwibawa dan berintegritas? Metode penelitian yang digunakan adalah penelitian socio-legal atau non doktrinal. Hasil penelitian ini menunjukkan bahwa: pertama, program-program pelatihan hakim sangat diperlukan sebagai upaya untuk mewujudkan hakim yang profesional, berwibawa dan berintegritas. Selain itu, pelatihan-pelatihan tersebut juga sebagai media untuk meningkatkan kualitas putusan hakim serta kompetensi hakim, baik kompetensi profesional, kompetensi personal, kompetensi sosial, maupun kompetensi kepemimpinan. Kedua, model program peningkatan kompetensi hakim untuk mewujudkan hakim profesional, berwibawa dan berintegritas yakni melalui pelatihan secara terintegrasi dan berkesinambungan atau berkelanjutan.

Kata-kata Kunci : Kompetensi; pelatihan; hakim

1 Artikel ini dibuat berdasarkan Hasil Penelitian dengan Surat Perjanjian Pelaksanaan Penelitian Hibah Percepatan Guru Besar Universitas Muhammadiyah Purwokerto Nomor : A11-III/580-S.Pj./LPPM/XI/2017 


\section{Pendahuluan}

Kemampuan seorang hakim dalam mengambil putusan diperoleh dari pendidikan sebelum menjadi hakim (vorverstandnis) dan pengalaman yang diperoleh selama karir yang dijalani. Sebagaimana pendapat Soejono Koesoemo Sisworo dengan mengutip Josef Esser ${ }^{2}$, putusan yang diambil oleh hakim dapat terjadi secara intuitif setelah hakim menelaah secara ringkas cermat atas fakta-fakta dari perkara yang diajukan kepadanya. Hal ini juga dikemukakan oleh Andi Andojo Soetjipto ${ }^{3}$, bahwa seorang hakim dikategorikan sebagai hakim yang mumpuni yaitu dalam arti berpikiran matang. Seorang hakim adalah seorang yang terpelajar dan berpengalaman disertai memiliki "indera keenam" yang membuat perbandingan dengan kejadian-kejadian yang sama di masa lalu sampai pada suatu titik pandangan yang dijadikan analisis berikutnya.

Kurangnya pelatihan bagi hakim merupakan kendala yang bersifat internal bagi hakim. Sebagaimana dikemukakan Fence M. Watu4, bahwa kendala yang dihadapi hakim dalam mewujudkan kepastian hukum, keadilan dan kemanfaatan dapat dibedakan menjadi kendala internal dan kendala eksternal. Kendala internal berasal dari dalam yaitu pengangkatan hakim, pendidikan hakim, penguasaan terhadap ilmu pengetahuan, moral hakim, kesejahteraan hakim. Sementara, kendala eksternal berasal dari luar yaitu kemandirian kekuasaan kehakiman, pembentukan undang-undang, sistem peradilan yang berlaku, partisipasi masyarakat, dan pengawasan hakim.

Hakim yang profesional, berwibawa dan berintegritas dapat dibangun melalui dua cara yaitu pendidikan ilmu hukum yang diperoleh sebelum menjadi hakim dan pelatihan yang berkelanjutan setelah menjadi hakim. Perilaku profesional seorang hakim, tidak terlepas dari pendidikan yang mereka terima, sebagaimana pendapat Satjipto Rahardjo ${ }^{5}$, dengan memberi porsi besar pada hlm. 273

2 Indriati Amarini, Keaktifan Hakim Dan Peradilan Administrasi, UMPurwokerto Press, Purwokerto, 2017,

3 Andi Andojo Soetjipto "Hakim Tunggal yang Gagap Hukum” tersedia di http://nasional.kompas.com diakses 1 Desember 2017

${ }^{4}$ Fence M. Watu "Kendala Hakim Dalam Menciptakan Kepastian Hukum, Keadilan Dan Kemanfaatan Di Peradilan Perdata", Jurnal Mimbar Hukum, Volume 25 Nomor 2 (2013), Fakultas Hukum Universitas Gajah Mada, hlm. 205

${ }^{5}$ Awaludin Marwan, Satjipto Rahardjo Sebuah Biografi Intelektual \& Pertarungan Tafsir Terbadap Filsafauk. Hukum Progresif, Thafa Media, Yogyakarta, 2013, hlm. 318 
diskursus seputar pendidikan tinggi hukum dikarenakan pendidikan adalah investasi jangka panjang yang paling bermakna dan berharga dalam konteks perubahan sosial kedepan yang lebih baik. Sedangkan perlunya pelatihan bagi hakim dikarenakan kecermatan dan ketuntasan putusan dipengaruhi pula oleh kematangan pengetahuan dan pengalaman. Soejono Koesoemo Sirworo ${ }^{6}$ mengemukakan, bahwa kekurangan mengenai hal tersebut akan menghasilkan putusan keliru atau putusan pia fraus. Arti umum "pia fraus" adalah penipuan untuk memberi keuntungan kepada orang yang ditipu. Putusan Hakim pia fraus merupakan putusan yang hanya berisi permainan kata-kata belaka yang tidak mempunyai arti banyak bagi yang berkepentingan.

Dalam rangka mendapatkan sumber daya manusia, yaitu hakim yang kompeten dengan kinerja yang objektif, berintegritas, dan profesional diperlukan pelatihan hakim yang berkelanjutan dan modern. Hal ini dikarenakan pembelajaran ilmu hukum bagi hakim tidak hanya berhenti pada pendidikan formal akademis. Oleh karena itu diperlukan pembelajaran secara terus-menerus (life-long learning) melalui pelatihan-pelatihan. Pembelajaran terus menerus diharapkan dapat mendorong fresh judgement yang bernilai landmark decision, sehingga tidak sekedar berfungsi sebagai legal craftsmanship dan legal mechanic tetapi mempunyai perspektif kritis untuk mengubah keadaan menjadi lebih adil.

Namun kenyataannya proses pembuatan putusan oleh hakim banyak mengandung permasalahan yang berimplikasi pada produk putusan. Berdasarkan hasil penelitian yang dilakukan oleh Komisi Yudisial RI pada 2007, ditemukan sebagai berikut: (1) Hakim dalam memutus perkara tidak kreatif dan tidak ada improvisasi; (2) Kekuatan interpretasi hakim tidak memadai; (3) Pola logika formal hakim sangat mendominasi putusan; (4) Hakim salah menerapkan hukum; (5) Putusan hakim hanya memenuhi aspek legal belaka; (6) Hakim berpikir sangat linier, normatif dan tidak progresif; (7) Hakim menderita kelelahan intelektual sehingga tidak mampu membuat putusan yang cerdas dan tidak mampu menguak cakrawala pemikiran dan tidak berani menembus ide-ide baru; (8) Putusan hakim sangat kaku dan terperangkap pada stuktur yang sudah baku; (9) Putusan hakim

\footnotetext{
${ }^{6}$ Indriati Amarini, Op.Cit., hlm. 275
} 
hanya mengkopi putusan sebelumnya; (10) Hakim tidak mau belajar membuat analisis hukum yang cerdas dan tajam; (11) Hakim tidak kreatif dalam menemukan konstruksi hukum; (12) Putusan hakim melukai rasa keadilan masyarakat; (13) Putusan hakim mencerminkan keadilan formal; (14) Putusan hakim dalam perkara korupsi, hukumannya terlalu ringan; (15) Ratio decidendi hakim dalam putusan lemah, sehingga termasuk bad law; (16) Hakim hanya berperan sebaga moderator; (17) Hakim hanya sebagai corong undang-undang; (18) Hakim tidak menyelesaikan sengketa justru menciptakan sengketa baru; (19) Hakim kurang memperhatikan kepentingan umum; (20) Pertimbangan hakim sangat kering7.

Upaya pembaruan peradilan telah dilakukan pasca penerapan sistem peradilan satu atap (one roof system) di bawah Mahkamah Agung RI. Mahkamah Agung mempunyai serangkaian tanggung jawab dan peran strategis baik dalam bidang yudisial maupun bidang teknis non yudisial yang meliputi bidang manajemen, administrasi, personel, finansial maupun sarana dan prasarana lembaga peradilan. Dalam rangka mendukung penerapan sistem peradilan satu atap (one roof system), Mahkamah Agung pada 2003 menyusun Cetak Biru dan Kertas Kerja Pembaruan Sistem Pendidikan dan Pelatihan (Diklat) Hakim. Sejak 2005 sampai dengan 2009 Mahkamah Agung membangun gedung dan asrama Pusat Pendidikan dan Pelatihan di Megamendung Bogor. Selanjutnya dilakukan pembenahan kurikulum, silabi dan modul pendidikan dan pelatihan baik bagi para peserta diklat maupun para tenaga pengajar.

Dalam mewujudkan visi badan peradilan (badan peradilan yang agung) sebagaimana disebutkan dalam cetak biru pembaharuan Badan Peradilan 20102035, salah satunya adalah dengan penggunaan atau penerapan Sumber Daya Manusia yang berbasis kompetensi (Competency Based Human Resources Management). Sistem ini dipahami sebagai satu pemahaman perspektif yang luas yang mencakup pengembangan perencanaan strategis, implementasi dan hasil perubahan yang terjadi dari pembangunan sistem SDM yang terintegrasi ${ }^{8}$.

\footnotetext{
${ }^{7}$ M. Syamsudin, "Rekontruksi Perilaku Etik Hakim Dalam Menangani Perkara Berbasis Hukum Progresif”, Jurnal Hukum Edisi Khusus Vol. 18 Oktober 2011, Fakultas Hukum Universitas Islam Indonesia Yogyakarta.

${ }^{8}$ Cetak Biru Pembaruan 2010-2035, 2010, hlm. 49
} 


\section{Rumusan Masalah}

Berdasarkan latar belakang terurai di atas, ada dua permasalahan yaitu: Pertama, mengapa diperlukan peningkatan kompetensi hakim melalui program pelatihan-pelatihan hakim? Kedua, bagaimanakah model program peningkatan kompetensi hakim dalam rangka mewujudkan hakim profesional, berwibawa dan berintegritas?

\section{Tujuan Penelitian}

Penelitian ini bertujuan: Pertama, menganalisis perlunya peningkatan kompetensi hakim melalui pelatihan-pelatihan hakim. Kedua, mengevaluasi program peningkatan kompetensi hakim melalui pelatihan dalam rangka mewujudkan hakim profesional, berwibawa dan berintegritas

\section{Metode Penelitian}

Penelitian ini berpijak pada paradigma hukum di samping sebagai fakta, juga sebagai gugusan nilai, sebagaimana pandangan sosiologi normatif atau oleh Nonet disebut "normative or morally approach". Penelitian ini digolongkan ke dalam doktrin hukum (legal doctrine) sebagai an empirical discipline. Oleh karena itu, penelitian ini merupakan jenis penelitian socio-legal atau nondoktrinal (socio legal or nondoctrinal research) ${ }^{9}$.

Sebagai penelitian non doktrinal atau sociolegal, mengikuti pandangan bahwa studi sosiolegal dilihat sebagai alternatif interdisipliner. Sosio dalam studi sosio legal tidak menunjuk pada sosiologi atau ilmu-ilmu sosial, tetapi mempresentasikan saling berhadapan dengan konteks tempat hukum berada. Oleh karena itu, penelitian ini merupakan penelitian kualitatif dengan tidak mengesampingkan peraturan perudang-undangan sebagaimana penelitian sosiologi hukum murni. Penelitian ini secara spesifik berkarakter perbandingan hukum kritis (critical comparative law) yaitu program pelatihan hakim di Korea Selatan dan penguasaan kompetensi hakim di Jerman.

${ }_{9}^{9}$ Hari Purwadi et. all. "Konsekuensi Transplatasi Hukum Terhadap Pancasila Sebagai Norma Dasar Dan Hukum Lokal", Jurnal Hukum Yustisia Edisi 9, Januari - Apil 2015, Fakultas Hukum Universitas Sebelas Maret, Surakarta, hlm. 50 


\section{Hasil Penelitian dan Pembahasan}

\section{Peningkatan Kompetensi Hakim Melalui Program Pelatihan Hakim}

Hakikat dasar pembentukan peradilan adalah menempatkan hakim dan pengadilan untuk selalu menjadi penyeimbang dalam berbagai lapisan kehidupan berbangsa dan bernegara. Sebagaimana dikemukakan Florina Mitrofan bahwa Constitutional principle of the independence of judges is an essensial guarantee for any system of law, reflected in the procedure of the recruitment and promotion of judge... ${ }^{10}$.

Seorang hakim dalam melaksanakan kewajibannya tidak terlepas dan dipengaruhi oleh sistem nilai yang dianut. Sebagaimana tercantum dalam beberapa teori yaitu: Pertama, Realism yaitu suatu studi tentang hukum sebagai sesuatu yang benar-benar nyata dilaksanakan ketimbang sekedar hukum sebagai sejumlah aturan yang hanya termuat dalam perundang-undangan tetapi tidak pernah dilaksanakan. Sebagaimana Oliver Wendell Holmes mengatakan "the life of the law has not been logic; but has been experience". Kedua, Behavioral Jurisprudence yang fokus utama pendekatan dari aspek perilaku. Perilaku hakim tidak bisa dilepaskan dari sikap-sikap individual yang melekat pada pribadi hakim. Berdasarkan teoriteori tersebut maka seorang hakim dalam mengeluarkan putusan sesungguhnya dipengaruhi banyak faktor diantaranya adalah pendidikan dan pelatihan hakim. Sebagaimana dikemukakan Richard A. Posner11 bahwa: ...institusional factors such as how clear or unclear the law is, salary and workload, and the structure of judicial promotion also influence judicial behavior.

Hanya hakim yang baik yang diharapkan dapat menghasilkan putusan yang berkualitas. Putusan hakim yang berkualitas merupakan cerminan kepiawaian dan kemampuan hakim di dalam memutus perkara. Adapun makna putusan yang berkualitas ialah putusan yang mampu melihat dan menyelesaikan perkara secara holistik baik secara kuantitatif, kualitatif maupun komplementatif baik dari aspek teoritis maupun praktis. ${ }^{12}$ Secara teoritis berarti putusan itu dapat

\footnotetext{
${ }^{10}$ Florina Mitrofan, "The Independence of Judge-a Guarantee of the Rule of Law State”, dalam Spesial Issue JL \& Admin Sci. 93 (2015)

${ }^{11}$ Richard A. Posner, How Judges Think, Harvard University Press, Cambridge, Massachussetts, England, 2010, hlm. 10.

12 A. Mukti Arto, "Putusan Yang Berkualitas Mahkota Bagi Hakim Mutiara Bagi Pencari Keadilan”, dalam Majalah Hukum Varia Peradilan No. 296 Juli 2010, hlm.23.
} 
dipertanggungjawabkan atau telah sesuai dengan teori yang telah teruji kebenarannya, sedangkan secara praktis berarti putusan itu telah mencapai sasaran yang diharapkan atau terselesaikannya sengketa dengan tegaknya hukum dan keadilan dan juga dapat dipraktikkan (dilaksanakan). Apabila putusan telah memenuhi syarat teoritis (das sollen) dan telah memenuhi syarat praktis (das sein) maka dapat dikategorikan sebagai putusan berkualitas ${ }^{13}$.

Selanjutnya A. Mukti Arto menjelaskan bahwa, secara teoritis putusan hakim harus memenuhi syarat: Pertama, ilmiah yaitu penetapan dan putusan hakim harus memuat pertimbangan hukum hakim yang didasarkan pada alasan dan dasar hukum yang tepat dan benar. Kedua, mencerminkan nilai-nilai filosofis Pancasila yang telah menjadi falsafah dan pandangan hidup bangsa Indonesia. Ketiga, putusan hakim harus sejalan dengan tujuan hukum nasional. Keempat, memenuhi syarat yuridis, hal ini merupakan syarat dan ciri utama serta kerangka inti suatu putusan. Kelima, memenuhi syarat sosiologis, setiap penyelesaian hukum harus sedemikian rupa sehingga dapat diterima secara yuridis, sosiologis dan filosofis. Sifat kodrati manusia adalah bersifat individual dan sekaligus sosial. Syarat sosiologis sekurang-kurangnya mencakup unsur memenuhi rasa keadilan, memulihkan hubungan sosial dan memberi kemanfaaan atau kesejahteraan. Keenam, memenuhi syarat psikologis, putusan hakim harus dapat memberikan rasa aman dan tenteram, rasa damai dan rasa puas secara psikologis. Ketujuh, memenuhi syarat religius karena putusan dijatuhkan demi keadilan berdasarkan Ketuhanan Yang Maha Esa. Oleh karena itu, putusan tidak boleh bertentangan dengan hukum yang dikehendaki Tuhan. Putusan harus dapat dipertanggungjawabkan di hadapan Tuhan. Sedangkan syarat putusan hakim secara praktis harus memenuhi 2 syarat yaitu: Pertama, tuntas artinya habis yakni selesai dengan menyeluruh, sempurna dan tidak ada lagi yang tersisa. Kedua, final artinya tahap terakhir dari rangkaian pemeriksaan.

Sri Sutatiek ${ }^{14}$ menambahkan bahwa pengertian putusan pengadilan yang berkualitas adalah putusan pengadilan yang adil bagi sebagian besar masyarakat

13 Ibid.

14 Sri Sutatiek, "Akuntabilitas Moral Hakim Dalam Memeriksa, Mengadili Dan Memutus Perkara Agar Putusannya Berkualitas”, dalam Jurnal Arena Hukum, Vol. 6 No. 1, 2013, hlm. 5 
dan putusan tersebut dapat dilaksanakan dalam rangka menciptakan ketertiban, kepastian dan kemanfaatan. Adapun indikatornya adalah putusan tersebut tidak dipermasalahkan oleh sebagian besar masyarakat, putusan tersebut tidak mengandung kontroversi yang berlebihan baik dalam sisi substansi perkara maupun substansi hukum yang digunakan sebagai dasar mengadili dan putusan tersebut sesuai dengan kondisi jaman sehingga dapat dilaksanakan.

Hakim membuat putusan yang berkualitas sebagaimana terurai di atas, pintu masuknya tetap melalui "teks" dalam hal ini undang-undang atau kodifikasi sebuah regulasi. Namun hal tersebut hanyalah starting point bagi hakim untuk mengelaborasi suatu perkara sehingga dapat ditempatkan pada "konteksnya". Penempatan "teks pada konteks" atau sebaliknya penyandingan "konteks ke dalam teks" secara sederhana dalam persidangan disebut sebagai proses pembuktian perkara dengan instrumen alat buktinya. Oleh karena sebuah regulasi hanya sebagai starting point maka kewajiban hakim pada tahap berikutnya adalah mengintepretasikan regulasi tersebut dengan tidak menutup kemungkinan terserapnya nilai-nilai dan aspirasi serta opini yang berkembang dalam masyarakat. Hakim dapat menggali dan menemukan nilai-nilai hukum yang baik dan benar sesuai dengan Pancasila. ${ }^{15}$

Sebagaimana kualitas seorang pemahat dilihat dari detail patung pahatannya. Kualitas arsitek diukur dari cita rasa bangun ruangnya. Sedangkan kualitas seorang hakim bisa dilihat dalam pertimbangan atau alasan-alasan yang dituangkan dalam putusan-putusannya. Putusan hakim tidak hanya berdiam diri di menara gading, teralienasi dari masyarakatnya. Tugas hakim dalam mewujudkan keadilan tidak terlepas dari putusan yang dihasilkan. Menurut Busthanul Arifin ${ }^{16}$, seorang hakim haruslah learned in law dan juga skilled in law yaitu selain memahami benar-benar substansi dan arti hukum, juga dia harus terampil dalam penerapan hukum itu. Di tangan hakim ilmu hukum menjadi applied science. Para hakimlah yang memberi nyawa pada pasal-pasal undang-

${ }^{15}$ Jimly Maruli, “Dicari Putusan Yang Progresif”, Majalah Hukum V aria Peradilan, No. 293 April 2010, hlm.

${ }^{16}$ Busthanul Arifin, "Sepanjang Jalan Kenangan Bersama Bismar Siregar, Sang Hakim”, V aria Peradilan No. 282 Mei 2009, hlm. 67 
undang dan peraturan-peraturan lain yang terdiri dari huruf-huruf mati karena yang dihadapi sehari-hari dalam tugasnya adalah hubungan-hubungan hukum dari manusia yang hidup dalam masyarakat yang terus berubah. Oleh karena itu hakim "are forever condemmed for the rest of their lives to continue studying the law".

Ada beberapa model pelatihan hakim di berbagai negara. Sebagai bahan perbandingan, penulis mengambil model pelatihan kehakiman di Korea Selatan. Korea Selatan sebagai salah satu negara di Asia yang dikenal dengan The Land of the Morning Calm, telah menunjukkan kemajuan yang cukup signifikan di berbagai bidang ${ }^{17}$. Kemajuan tersebut dikarenakan negara Korea Selatan lebih menekankan pada aspek sumber daya manusia. Salah satu program tersebut adalah di bidang penegakan hukum.

Seseorang yang akan terjun dalam profesi hukum di Korea Selatan harus mengikuti ujian jabatan profesi hukum terlebih dahulu yang diselenggarakan oleh Departemen Kehakiman, kemudian mengikuti pelatihan kehakiman yang diadakan oleh "The Judicial Research and Training Institute" (JRTI). JRTI adalah sebuah lembaga yang berada di bawah Mahkamah Agung, untuk mendidik prinsip-prinsip dasar praktis dan etika moral yang harus dimiliki profesi hukum. Lembaga ini didirikan pada 1971. Awalnya lembaga ini bertujuan untuk mendidik para hakim dan jaksa saja, tetapi sejak 1997 mengubah tujuannya untuk mendidik pengacara agar mempunyai daya saing internasional. Sistem pendidikan di JRTI dibagi menjadi 4 semester, memakai sistem kredit, sistem jurusan dan sangat mementingkan pada pendidikan etik moral dan bidang spesialisasi ${ }^{18}$.

Selain melakukan pelatihan untuk orang-orang yang baru lulus, lembaga ini juga mengadakan pelatihan penyegaran untuk para hakim, pelatihan untuk para calon pembantu hakim dan pelatihan khusus untuk calon profesi hukum di militer. Sebagai sebuah lembaga pendidikan, JRTI yang berada di bawah Mahkamah Agung tersebut mempunyai kedudukan yang setara dengan Pengadilan Tinggi. Untuk menghadapi globalisasi maka diperlukan kemampuan mengakses teknologi informasi berupa komputer, internet dan kemampuan berbahasa asing.

${ }_{17}$ Nani Indrawati, "Selayang Pandang Tentang Judicial System Di Korea Selatan”, dalam Majalah Hukum Varia Peradilan No. 269 April 2008, hlm. 15

${ }^{18}$ Ibid., hlm. 16 
Penguasaan bahasa asing dan hukum negara lain adalah syarat wajib bagi profesi hukum di jaman globalisasi, sehingga sejak 2006 ada mata kuliah Bahasa Inggris Hukum dan Pengantar Hukum Amerika Serikat. JRTI menyediakan beberapa program untuk membangkitkan pelayanan dan etika moral bagi para peserta, terutama mata kuliah Etika Kehakiman yang diharapkan agar para calon profesi hukum tersebut dapat memahami kesengsaraan dan penderitaan rakyat.

Berdasarkan Panduan Program Pendidikan dan Pelatihan Calon Hakim Terpadu 2010 yang dikeluarkan olen Mahkamah Agung RI, seorang hakim diharapkan mempunyai beberapa kompetensi. ${ }^{19}$ Kompetensi yaitu: (1) Pengetahuan, keterampilan, dan kualitas yang mengarah pada perilaku; (2) Dapat dikenali dalam diri seseorang; (3) Dapat dinilai; (4) Dapat diperbaiki menjadi lebih baik dengan tingkatan tertentu melalui pendidikan dan pelatihan. Berikut adalah daftar kompetensi ${ }^{20}$ yang harus dimiliki meliputi: (1) Dampak putusan yaitu calon hakim harus mengikuti perkembangan (sosial) terkait peradilan dan dapat mempertimbangkan kepentingan para pihak. Selain itu, calon hakim juga mengikuti perkembangan putusan itu diterima secara sosial; (2) Formasi putusan yaitu calon hakim dapat membuat putusan yang secara hukum dapat dipertanggungjawabkan, adil, berargumen dengan baik, dan menggunakan bahasa Indonesia yang baik dan benar; (3) Analisis masalah yaitu calon hakim dapat mengidentifikasi masalah, menghubungkan dan menyimpulkan berdasarkan alasan yang cukup (4) Kerja sama yaitu calon hakim siap dan dapat bekerja sama; (5) Kemampuan untuk berkomunikasi secara lisan yaitu calon hakim mampu menyampaikan informasi secara lisan dengan jelas dan ringkas; (6) Kemampuan untuk mengutarakan pendapat secara tertulis; (7) Sensitivitas sosial yaitu calon hakim sebaiknya mendengarkan dan dapat menyelami cara berpikir orang lain sehingga mampu mengidentifikasi perasaan dan kebutuhan orang lain; (8) Integritas yaitu calon hakim sebaiknya dapat berperilaku dalam kata dan perbuatan sesuai dengan norma sosial, etika, dan nilai yang berlaku umum walaupun dalam keadaan sulit dan di bawah tekanan; (9) Kepercayaan diri yaitu

\footnotetext{
${ }^{19}$ Lihat Mahkamah Agung RI, Program Pendidikan Dan Pelatihan Calon Hakim Terpadu, 2010, hlm. 9-13

${ }^{20}$ Disarikan dari sejumlah kompetensi yang harus dimiliki seorang caon hakim, sebagaimana tercantum dalam Panduan Pendidikan dan Pelatihan calon hakim (PPC Hakim Terpadu)
} 
calon hakim memiliki kemampuan untuk mengambil keputusan yang beralasan dan bertindak dengan penuh percaya diri meskipun dalam keadaan sulit; (10) Kemampuan untuk memutuskan (pembuatan putusan) yaitu calon hakim tidak takut mengambil keputusan dan memecahkan masalah; (11) Kemampuan untuk belajar yaitu calon hakim bersedia dan berkemampuan untuk berkembang demi meningkatkan kemampuan profesionalismenya secara luas dan mendalam; (12) Refleksi diri yaitu calon hakim mencari umpan balik untuk diri sendiri secara aktif. Selain itu, ia juga siap memperbaiki kelemahannya. Ia harus realistis untuk menilai dirinya mengenai kekuatan dan kelemahan diri sendiri; (13) Kemampuan untuk mengatur pekerjaan sendiri yaitu calon hakim harus mampu mengatur dan menyelesaikan pekerjaannya sendiri secara efisien dan efektif; (14) Disiplin yaitu calon hakim harus memenuhi prosedur dan aturan perilaku yang telah ditetapkan; (15) Mendengar yaitu calon hakim menaruh perhatian pada kata-kata yang telah diucapkan dan mengerti pokok pembicaraan; (16) Impartialitas yaitu Calon hakim memenuhi kewajibannya tanpa preferensi atau prasangka buruk. Pada dasarnya, ia harus menghindari konflik kepentingan; (17) Kemandirian yaitu calon hakim harus mandiri dalam membuat putusan, tanpa dipengaruhi oleh orang lain dengan cara apa pun; (18) Ketelitian yaitu calon hakim sebaiknya mempunyai kemampuan untuk bekerja secara tepat dan tidak membuat kesalahan, memeriksa kembali pekerjaannya dan orang lain untuk menghindari kesalahan.

Namun nampaknya tidak ada kategori kompetensi secara khusus yang harus dimiliki seorang hakim di Indonesia setelah pelatihan dan magang dilaksanakan. Sebagai perbandingan, penulis membuat tabel kompetensi yang harus dimiliki oleh hakim di Jerman, ${ }^{21}$ meliputi :

Tabel 1.

Kompetensi Hakim Setelah Mengikuti Program Pelatihan Di Jerman

\begin{tabular}{llll}
\hline \multicolumn{1}{c}{$\begin{array}{c}\text { I. Profesional } \\
\text { Competence }\end{array}$} & \multicolumn{1}{c}{$\begin{array}{c}\text { II. Personal } \\
\text { Competence }\end{array}$} & $\begin{array}{c}\text { III. Social } \\
\text { Competence }\end{array}$ & $\begin{array}{c}\text { IV. Competence } \\
\text { to lead }\end{array}$ \\
\hline Professional & General elements of & Ability to & Clear \\
Qualification & personality & work in team & instruction \\
- Wide knowledge of & $\bullet$ Broad interest & & \\
the law & $\bullet$ Natural authority & & \\
\hline
\end{tabular}

${ }^{21}$ Johanes Riedel, "Training and Recruitment Of Judges in Germany", International Journal For Court Administration, Volume 5 No. 2, October 2013 
- Ability to apply the law in practice

- Ability to acquaint oneself with new legal fields

- Good judgement

- Ability to apply information technology

Understanding judicial office

- Impartiality

- Prepared to actively uphold the values of the constitution

- Prepared to defend against undue influence

- Prepared to take responsibility for judicial decisions

- Awareness of the influence of private conduct on judicial office
- Prepared to accept difficult duties

- Awareness of one's strengths and weakesses

- Control of one's strengths and weaknesses

- Conrol of one's emotions of Sense of duty and responsibility

- Awareness of social responsibility

- Prepared to accept responsibility for the judicial administration

- Able to assess consequences of decisions

- Responsible handling of large workload

- Openness towards lay judges and court staff

Ability to present Ability to cope with argumens and to the workload convince

- Precise phrasing

- Ability to define issues in complex cases

- Giving reasons thoroughly with respect to the individual case

- Opennes
- Physical and psychologica fitness

- Prepared to accept additional duties

- Able to work fast under prssure and with concentration

- Maintaining standars even with a larger work load

\author{
Ability to \\ communicate
}

Ability to deal with conflicts and to mediate

- Prepared for compromises

- Fairness, positive approach in dealing with colleagues

- Constructive critism

- Abbility to mediate

- Being accepted as an authority 


\begin{tabular}{|c|c|c|c|}
\hline $\begin{array}{l}\text { Ability to conduct } \\
\text { hearings and } \\
\text { interrogation } \\
\text { - Being thoroughly } \\
\text { prepared } \\
\text { - Knowledge of the } \\
\text { court files and } \\
\text { documents } \\
\text { - Planning and } \\
\text { structuring of trials } \\
\text { - Respect for the } \\
\text { interests of the parties } \\
\text { - Understanding, } \\
\text { sensitiveness and } \\
\text { patience with parties } \\
\text { - Clear view of chances } \\
\text { for settlements } \\
\text { Competence } \\
\text { teaching } \\
\text { - Prepared to instruct } \\
\text { students in } \\
\text { preparatory service } \\
\text { - Diligent correction of } \\
\text { students papers }\end{array}$ & $\begin{array}{l}\text { Ability to decide } \\
\text { - Decide swiftly and } \\
\text { responsibility } \\
\text { - Prepared to face } \\
\text { necessary disputes } \\
\text { Flexibility and } \\
\text { preparedness for } \\
\text { innovations } \\
\text { - Opennes towards } \\
\text { new technologies } \\
\text { - Opennes towards } \\
\text { modernisation of } \\
\text { courts } \\
\text { - Prepared to work in } \\
\text { different court } \\
\text { structures } \\
\text { - Ability to develop } \\
\text { new solutions }\end{array}$ & $\begin{array}{l}\text { Awareness of } \\
\text { service aspects } \\
\text { - Respect for } \\
\text { interests and } \\
\text { concerns of } \\
\text { parties and } \\
\text { witnesses } \\
\text { - Politeness } \\
\text { - Keeping to } \\
\text { schedules } \\
\text { - Taking the } \\
\text { necessary } \\
\text { amount of } \\
\text { time }\end{array}$ & $\begin{array}{l}\text { Opennes for } \\
\text { concerns of staff }\end{array}$ \\
\hline
\end{tabular}

Sumber: Johanes Riedel, 2013

\section{Model Program Peningkatan Kompetensi Hakim Melalui Pelatihan Hakim yang Terintegrasi dan Berkelanjutan}

Hakim yang berkualitas hanya dapat lahir melalui sistem rekrutmen, seleksi dan pelatihan yang baik. Odette Buitendam menyatakan, bahwa good judge are not 
born but made. ${ }^{22}$ Dalam konteks pengembangan organisasi lembaga peradilan yaitu Mahkamah Agung, hukum sebab akibat dapat dimaknai bahwa maju dan mundurnya suatu organisasi memiliki hubungan garis lurus dengan aturan tertentu yang secara sadar diciptakan untuk itu. Dengan demikian, kesuksesan organisasi merupakan akibat langsung atau tidak langsung dari sebab-sebab atau tindakan tertentu yang direkayasa secara sadar dan terencana ${ }^{23}$.

Terdapat beberapa pandangan tentang kriteria hakim yang baik antara lain ; memiliki kemampuan hukum (legal skill), berpengalaman yang memadai, memiliki integritas, memiliki kesehatan yang baik, mencerminkan keterwakilan masyarakat, memiliki nalar yang baik, memiliki visi yang luas, memiliki kemampuan berbahasa dan menulis, mampu menegakkan hukum negara dan bertindak independen dan imparsial dan memiliki kemampuan administratif dan efisien. ${ }^{24}$

Teknik membuat putusan yang baik adalah seni "art" bukan sekedar hanya ilmiah "science". Oleh karena seni maka seseorang dapat sepanjang hidupnya mengembangkan dan melalui proses belajar senantiasa mengarah naluri keindahannya. Sebagaimana dikemukakan James E. Bond ${ }^{25}$ dalam bukunya yang berjudul The Art of Judging, yang menyampaikan bahwa: ada dua perbedaan styles of judging antara judicial craftsmen dan judicial statesmen yaitu "Judicial craftsmen look backward for guidance: to the text of the constitution, the original understanding of the text and historical experience. Judicial statesmen look forward: to moral and political ideals and notions of the public good".

Program pelatihan bagi hakim di Indonesia terdiri dari dua kategori yaitu pelatihan umum dan pelatihan sertifikasi. Ruang lingkup pelatihan umum lebih luas. Sedangkan ruang lingkup pelatihan sertifikasi lebih spesifik yaitu peradilan anak, tindak pidana korupsi, lingkungan hidup dan niaga. Pelatihan hakim merupakan satu hal yang wajib dilakukan Mahkamah Agung. Namun tidak semua hakim dipanggil

\footnotetext{
${ }^{22}$ Rifqi Sjarief Assegaf, "Hanya Hakim Yang Bersih Dan Kompeten Yang Layak Adili Koruptor”, Jurnal Kriminologi Indonesia, Vol. 2 No. 1 Januari 2002, Fakultas Ilmu Sosial dan Ilmu Politik, Universitas Indonesia, hlm. 9

${ }^{23}$ Bagir Manan, Memulibkan Peradilan Yang Berwibawa Dan Dihormati, Ikahi, Jakarta, 2008, hlm. 1

${ }^{24}$ Abdullah, Mustafa, Laporan Penelitian Putusan Hakim Tabun 2007, Tersedia di http://komisiyudisial.go.id. Diakses pada tanggal 15 Oktober 2017

${ }^{25}$ James E. Bond, The Art OfJudging, New Brunswick, USA, 2009, hlm. 1
} 
untuk pelatihan. Hal ini dikarenakan jumlah hakim di tingkat pertama sebanyak 3.164 orang dan hakim di pengadilan tinggi sebanyak 738 orang. ${ }^{26}$

Semua hakim pada prinsipnya harus mengikuti pelatihan yang dilakukan secara rutin. ${ }^{27}$ Namun, karena jumlah hakim yang relatif banyak dan dana terbatas maka bisa melakukan pelatihan hakim dengan model Training of Trainer. Training of Trainer (ToT) adalah pelatihan yang diperuntukkan bagi orang yang diharapkan setelah selesai pelatihan mampu menjadi pelatih dan mampu mengajarkan materi pelatihan tersebut kepada orang lain. Hakim yang dipanggil untuk mengikuti pelatihan, setelah kembali ke pengadilan masing-masing wajib transfer of knowledge kepada hakim yang tidak mengikuti pelatihan. Selain itu sudah saatnya pelatihanpelatihan tidak harus dilakukan terpusat di Badan Litbang Kumdil Megamendung, namun dilaksanakan juga di Pengadilan Tinggi wilayah masing-masing hakim yang ditunjuk mengikuti pelatihan.

Program pelatihan calon hakim di Indonesia dilaksanakan setelah selesai proses rekrutmen calon hakim. Ada tahapan pelatihan dan magang yang harus ditempuh oleh calon hakim selama dua tahun sebelum diangkat menjadi hakim. Saat ini, proses pendidikan calon hakim dibagi dalam tiga tahap yaitu: (1) Pradiklat, calon hakim berstatus Pegawai Negeri Sipil (PNS) dan dalam tahap menunggu untuk mengikuti diklat. (2) Diklat, hakim mengikuti pendidikan calon hakim di Pusat Pendidikan dan Latihan (Pusdiklat) MA di Mega Mendung, Ciawi. (3) Pascadiklat, calon hakim ditempatkan di Pengadilan Tingkat Pertama untuk jangka waktu yang tidak ditetapkan, tetapi minimal kurang lebih satu tahun sebelum pengangkatannya sebagai hakim. Tahapan kegiatan dan jangka waktunya bisa dilihat dalam tabel di bawah :

Tabel 2.

Tahapan pelatihan dan Magang Bagi Calon Hakim Di Indonesia

\begin{tabular}{lcc} 
& Kegiatan & Minggu \\
\hline 1 & Diklat I & 2 \\
2 & Magang I & 22 \\
3 & Diklat II & 13 \\
4 & Magang II & 26 \\
\hline
\end{tabular}

26 Belum Semua Hakim Mendapatkan Pelatihan Umum dan Sertifikasi, http://nasional.kompas.com, diakses 28 Januari 2018

${ }^{27}$ Heni Hendrawati dkk, “Aspek Penegakan Kode Etik Hakim Dalam Mewujudkan Kekuasaan Kehakiman Yang Bermartabat”, V aria Justica, Vol. 12 No. 1, Maret (2016), hlm. 100 


\begin{tabular}{lcc}
\hline 5 & Diklat III & 13 \\
6 & Magang III & 30 \\
\hline & Total & 106 \\
\hline
\end{tabular}

Sumber : Program Pendidikan Dan Pelatihan Calon Hakim Terpadu, 2010

\section{Penutup}

Berdasarkan uraian analisis di atas, dapat disimpulkan bahwa, pertama, program-program pelatihan hakim sangat diperlukan sebagai upaya untuk mewujudkan hakim yang profesional, berwibawa dan berintegritas. Selain itu, pelatihan-pelatihan tersebut juga sebagai media untuk meningkatkan kualitas putusan hakim serta kompetensi hakim, baik kompetensi profesional, kompetensi personal, kompetensi sosial, maupun kompetensi kepemimpinan. Mahkamah Agung merupakan institusi yang wajib melaksanakan pelatihan terhadap seluruh hakim. Namun, tidak semua hakim dipanggil untuk pelatihan sehingga dampak atau hasil perubahan yang dimaksud belum maksimal karena kurang dapat terukur dan objektif. Kedua, model program peningkatan kompetensi hakim untuk mewujudkan hakim professional, berwibawa dan berintegritas yakni melalui pelatihan secara terintegrasi dan berkesinambungan atau berkelanjutan.

Adapun rekomendasi yang diajukan dalam penelitian ini, sebagai upaya mewujudkan hakim yang profesional, berwibawa dan berintegritas, diantaranya: (1) program peningkatan kompetensi hakim diberikan kepada seluruh hakim melalui pelatihan secara terintegrasi atau terpadu dan berkelanjutan atau berkesinambungan, (2) pelatihan hakim dapat dilakukan menggunakan model Training of Trainer (ToT), (3) seorang hakim setelah mengikuti pelatihan wajib transfer of knowledge kepada hakim yang tidak mengikuti pelatihan, (4) pelatihan hendaknya tidak terpusat akan tetapi juga dilaksanakan di wilayah hukum Pengadilan Tinggi masing-masing.

\section{Daftar Pustaka}

\section{Buku}

Amarini, Indriati, Keaktifan Hakim Dan Peradilan Administrasi, UMPurwokerto Press, Purwokerto, 2017.

A. Posner, Richard, How Judges Think, Harvard University Press, Cambridge, Massachussetts, England, 2010. 
E. Bond, James, 2009, The Art Of Judging, New Brunswick, USA

Marwan, Awaludin, Satjipto Rahardjo Sebuah Biografi Intelektual \& Pertarungan Tafsir Terhadap Filsafat Hukum Progresif, Thafa Media, Yogyakarta, 2013.

Cetak Biru Pembaharuan Mahkamah Agung, 2010

Panduan Pendidikan dan Pelatihan Calon Hakim (PPC Hakim Terpadu), 2010

Jurnal

Assegaf, Rifqi Sjarief, "Hanya Hakim Yang Bersih Dan Kompeten Yang Layak Adili Koruptor", Jurnal Kriminologi Indonesia, Fakultas Ilmu Sosial dan Ilmu Politik, Universitas Indonesia, Vol. 2 No. 1 Januari 2002,

Hendrawati, Heni, dkk, "Aspek Penegakan Kode Etik Hakim Dalam Mewujudkan Kekuasaan Kehakiman Yang Bermartabat", Varia Justica, Vol. 12 No. 1, Maret, 2016.

Mitrofan, Florina, "The Independence of Judge-a guarantee of the rule of law state", dalam Spesial Issue JL \& Admin Sci. 93, 2015.

Purwadi, Hari, et. all, "Konsekuensi Transplatasi Hukum Terhadap Pancasila Sebagai Norma Dasar Dan Hukum Lokal", Jurnal Hukum Yustisia Edisi 9, Januari - Apil 2015, Fakultas Hukum Universitas Sebelas Maret, Surakarta

Riedel, Johanes. "Training ang Recruitment Of Judges in Germany", International Journal For Court Administration, Volume 5 No. 2, October 2013.

Syamsudin, M, "Rekontruksi Perilaku Etik Hakim Dalam Menangani Perkara Berbasis Hukum Progresif", Jurnal Hukum Fakultas Hukum Universitas Islam Indonesia Yogyakarta, Edisi Khusus Vol. 18 Oktober 2011.

Sutatiek, Sri, "Akuntabilitas Moral Hakim Dalam Memerika, Mengadili Dan Memutus Perkara Agar Putusannya Berkualitas", dalam Jurnal Hukum Arena Hukum 2014, Tersedia di http:/ /arenahukum.ub.ac.id. diakses hari Minggu, 3 Desember 2017.

Wantu, Fence, "Kendala Hakim Dalam Menciptakan Kepastian Hukum, Keadilan Dan Kemanfaatan Di Peradilan Perdata", Jurnal Mimbar Hukum, Volume 25 Nomor 2, 2013.

\section{Majalah Hukum}

Arto, A. Mukti, Putusan Yang Berkualitas Mahkota Bagi Hakim Mutiara Bagi Pencari Keadilan, dalam Majalah Hukum Varia Peradilan No. 296 Juli 2010

Arifin, Busthanul, "Sepanjang Jalan Kenangan Bersama Bismar Siregar, Sang Hakim", Varia Peradilan No. 282 Mei 2009

Indrawati, Nani. "Selayang Pandang Tentang Judicial System Di Korea Selatan", Majalah Hukum Varia Peradilan No. 269 April 2008

Maruli, Jimly, “Dicari : Putusan Yang Progresif”, Varia Peradilan No. 293 April 2010, IKAHI, Jakarta 
Manan, Bagir, "Memulihkan Peradilan Yang Berwibawa Dan Dihormati”, IKAHI, Jakarta, 2008

\section{Perundang-undangan}

Undang-undang Nomor 48 Tahun 2009 tentang Kekuasaan Kehakiman (Tambahan Lembaran Negara Republik Indonesia Nomor 5076)

\section{Website}

Abdullah, Mustafa, Laporan Penelitian Putusan Hakim Tahun 2007, Tersedia di http:/ / komisiyudisial.go.id. diakses tanggal 15 Oktober 2017

Andi Andojo Soetjipto. "Hakim Tunggal yang Gagap Hukum", Tersedia di http:/ / nasional.kompas.com diakses tanggal 1 Desember 2017

Pejabat MA Ditangkap KPK Dan Hasil Survey Kepuasan Masyarakat ke Pengadilan", Tersedia di http://news.detik.com/berita/3143235 diakses tanggal 16 Februari 2016

Belum Semua Hakim Mendapatkan Pelatihan Umum dan Sertifikasi, http:/ / nasional.kompas.com, diakses tanggal 28 Januari 2018 